\title{
THE ANALYSIS OF BEEF CATTLE SUBSYSTEM AGRIBUSINESS IMPLEMENTATION IN CENTRAL JAVA PROVINCE， INDONESIA
}

\author{
T. Ekowati ${ }^{1,3}$, D.H. Darwanto ${ }^{1}$, S. Nurtini ${ }^{2}$ and A. Suryantini ${ }^{1}$ \\ ${ }^{1}$ Faculty of Agriculture, Gadjah Mada University \\ Jl. Flora, Bulaksumur Campus, Yogyakarta - Indonesia \\ ${ }^{2}$ Faculty of Animal Sciences, Gadjah Mada University, \\ Jl. Fauna, Bulaksumur Campus, Yogyakarta - Indonesia \\ ${ }^{3}$ Permanent Address : Faculty of Animal Agriculture, Diponegoro University \\ Tembalang Campus, Semarang 50275 - Indonesia \\ Corresponding E-mail:tiekowati@yahoo.co.id
}

Received September 29, 2011; Accepted November 03, 2011

\begin{abstract}
ABSTRAK
Penelitian dilakukan dengan tujuan untuk menganalisis penerapan subsistem agribisnis usaha ternak sapi potong di Jawa Tengah. Lokasi penelitian ditentukan secara purposive sampling berdasarkan Location Quotion (LQ) yaitu Kabupaten Rembang, Blora, Grobogan, Boyolali dan Wonogiri. Responden peternak ditentukan dengan metode quota sampling, setiap kabupaten diambil 40 responden. Data dianalisis dengan Structural Equation Model (SEM). Hasil penelitian menunjukkan bahwa subsistem agribisnis diterapkan dengan indeks cukup, yakni score untuk subsistem sarana produksi 0,693; proses produksi 0,721; pasca panen 0,684; pemasaran 0,626 dan Lembaga Pendukung Agribisnis adalah 0,691. Analisis menunjukkan bahwa model SEM adalah layak dengan nilai Chi-Square=0,952; RMSEA=0,000; Probabilitas=0,621 dan TL1=1,126. Analisis Critical Ratio (CR) menunjukkan bahwa subsistem agribisnis hulu berpengaruh terhadap proses produksi; subsistem proses produksi berpengaruh terhadap subsistem agribisnis hilir; subsistem agribisnis hilir berpengaruh terhadap pendapatan peternak, subsistem pemasaran berpengaruh terhadap subsistem agribisnis hilir dan Lembaga Pendukung Agribisnis berpengaruh terhadap subsistem agribisnis hilir dan pemasaran. Kesimpulan: penerapan subsistem agribisnis usaha sapi potong dilakukan dengan indeks penerapan cukup, setiap subsistem saling berhubungan dan berpengaruh terhadap penerapan agribisnis sapi potong.

Kata Kunci: penerapan subsistem agribisnis, Structural Equation Model (SEM), sapi potong, quota sampling, Location Quotion ( $L Q)$
\end{abstract}

\begin{abstract}
The study aimed to analyze the implementation of subsystem agribusiness on the beef cattle farming in Central Java. Five districts (Rembang, Blora, Grobogan, Boyolali and Wonogiri) were purposively chosen based on the value of Location Quotient (LQ). The study was conducted using quota sampling method. Forty respondents of each district were chosen randomly using quota sampling. Data were analyzed through Structural Equation Model (SEM). The results showed that each subsystem agribusiness had adequate potential score. The score of $0.693,0.721,0.684,0.626$, and 0.691 were given for up-stream subsystem, on-farm, down-stream subsystem, marketing and supporting institution, respectively. The results showed that the SEM model was feasible with Chi-Square value $=0.952$; RMSEA $=0.000$; Probability $=0.621$ and TL1 $=1.126$. The significant results of Critical Ratio $(\mathrm{CR})$ were: up-stream subsystem to the on-farm agribusiness; on-farm subsystem to down-stream agribusiness; down-stream subsystem to the farmer's income; marketing subsystem to the up-stream agribusiness and Supporting Institution to the marketing subsystem and down-stream agribusiness. The conclusion of research indicated that the implementation of beef cattle subsystem agribusiness had adequate index and give positive effect to the beef cattle agribusiness.

Keywords: subsystem agribusiness implementation, Structural Equation Model (SEM), beef cattle
\end{abstract} farming, quota sampling, Location Quotient (LQ) 


\section{INTRODUCTION}

Recently, the implementation of cattle farm agribusiness subsystem has not been well done (Ekowati, et al., 2006). Some influencing factors of it are the weakness of capital, technology and resources also bargaining position. The agribusiness-system approach to beef cattle is a system in which the synchronization of land, breeding, feeding practices, and management of beef cattle farming in order to achieve the objectives of agricultural development (food security, the implementation of agribusiness and improving the welfare of farmers) (Yusdja and Ilham, 2006). Moreover, cattle farming development should be focused on market oriented and is not just a production oriented.

According to Downey and Erickson (1987) and Saragih (2000), the concept of agribusiness system is synchronization and combination of the four functions of agribusiness and supporting institution, namely: 1) Up-stream agribusiness subsystem consists of planning and managing the availability of production facilities, technology and resources in order to meet the criteria of time, number, type, quality, product and price, 2) On-farm agribusiness system, this function has relationship with the criteria for site selection process, management of livestock and technology in order to increase production, 3) Down-stream agribusiness is a post-harvest activity which will give an agribusiness value added to receive a higher return of farmer's income, 4) Marketing subsystem, the development of cattle farming with agribusiness approach can be realized if the beef cattle farmers is able to compete in global market such as purchasing and collecting market information, 5) Supporting institutions of agribusiness are needed to support marketing facilities and financial, expansion of veterinary service, and giving management training for farmers.

The beef cattle farming in Central Java is characterized by inefficient small-scale farms and poor farming practices (Prasetyo et al., 2005; Mukson et al., 2010). The Central Java beef cattle production faces a number of basic problems which include limited farmer education and skills, marketing, poor farm management practices and limited access to capital. Based on this situation, all stakeholders in cattle farming must act together to be able to maximize resources and efforts in bringing about the necessary changes in order to improve the quality of live (Ekowati, et al., 2006). Moreover, several weaknesses of the Central Java beef cattle farming (Prasetyo et al., 2005; Yusdja and Ilham, 2004) are 1) Up-stream agribusiness system, and the main concern is feed availability; 2) On-farm agribusiness system. It has low level of farm efficiency, low level of market oriented, and small scale of farms; 3) Down-stream agribusiness subsystem. Some of major concerns are how increase output and technical efficiency level; 4) Marketing agribusiness subsystem. The major concern is bargaining position of the farmers and the dominan role of "blantik" (a person working on the livestock markets) in marketing system.

Taking into consideration the abovementioned, this study was attempted to analyze the implementation of agribusiness subsystem on the beef cattle farming in Central Java.

\section{MATERIALS AND METHODS}

The study was conducted using descriptive method. Descriptive research design involves observing and describing the behavior of a subject and describes data or characteristics about the population being studied (Nasir, 1988; Surachmad, 1998). Moreover, survey method was used for collecting data by asking questions to people who are thought to have desired information related with beef cattle develeopment. Five districts were purposively chosen based on the value of Location Quotient (LQ)>1. The LQ' score of $3.28 ; 2.23 ; 1,97 ; 1.38$; and 1.01 were given for Blora, Grobogan, Rembang, Boyolali and Wonogiri, respectively (BPS, 2009). The respondents (40 farmers of each district) were chosen randomly using quota sampling, hence the sample size in this study was 200 . The data were analyzed descriptively and statistically through Structural Equation Model.

Descriptive analysis was used to describe the application of agribusiness on the beef cattle farming. Agribusiness implementation was specified on each subsystem which was analyzed using scoring value with Likert scale. The values of Likert scale were 5; 4; 3; 2 and 1 for very good, good, moderate, somewhat good and not good, respectively. Afterwards, agribusiness implementation was analyzed by Index Approach: Index of agribusiness implementation $=$

$$
\frac{\text { score }}{\text { maximum score }} \times 100 \%
$$


The Index Indicates of the agribusiness implementation' level (Thamrin et al., 2007) is described in Table 1.

Structural Equation Model (SEM) was used to analyze the agribusiness subsystem implementation on beef cattle farming. The variables of $\mathrm{X}$ (endogen) and $\mathrm{Y}$ (exogen) in these study were used to construct the basic concept of SEM analysis. The variables of $\mathrm{X}$ and $\mathrm{Y}$ are presented in Table 2.

In addition, it was very important to measure the validity and reliability in these study. The validity and reliability of that test is used as part of the data collection process.

\section{The validity test}

Validity determines whether the research truly measures that which it was intended to measure or how truthful the research results are. Minimum requirement of validity test is correlated positively with maximum opportunities 0,05 .

$$
\begin{gathered}
r=\frac{\sum\left(X_{b j}-\bar{X}\right)\left(\sum Y j-\bar{Y}\right)}{\left.\sqrt{\left[\left(\sum X_{b j}-X\right)^{2}\right.}-\sum\left(Y_{j}-\bar{Y}\right)^{2}\right]} \\
\text { where: } \\
\mathrm{X}_{\mathrm{bj}}=\text { score of the variables } \mathrm{b} \text { to } \mathrm{j} \\
\mathrm{Y}_{\mathrm{j}}=\text { total score of variables } \mathrm{j}
\end{gathered}
$$

The t-test was used to determine the relationship among indicator variables using 5\% level of significance.

$$
t=r \sqrt{\frac{n-2}{1-r^{2}}}
$$

\section{Reliability test}

Reliability refers to the consistency of a measure. A test was considered reliable if the result is same repeatedly (Arikunto, 2004). Alpha Crombach ( $\alpha$ ) test was used in this reliability test.

$$
\alpha=\left[\{(\mathrm{k}):(k-1)\}\left\{1-\left(\sum \sigma_{b}^{2}: \sigma_{t}^{2}\right)\right\}\right]
$$

where:

$\alpha \quad=$ Reliability instrument $\mathrm{k} \quad=$ Number of questionnaire

$\sigma_{\mathrm{b}}^{2}=$ Variance of $b$

$\sigma_{\mathrm{t}}^{2}=$ Total variance

Testing structural model was built from several measurement models which have relationships or causality between the factors (Ferdinand, 2006). Hypothesis of factor confirmatory is :

$$
\begin{aligned}
& \text { Ho }: \operatorname{Cov}(\mathrm{S})=\operatorname{Cov}(\mathrm{P}) \\
& \text { Ha }: \operatorname{Cov}(\mathrm{S}) \neq \operatorname{Cov}(\mathrm{P})
\end{aligned}
$$

Likelihood ratio chi-square statistic $\left(\mathrm{X}^{2}\right)$ was used to testing the hypothesis, with the criteria : If $\mathrm{X}^{2} \geq 0.05$ the null hypothesis is accepted and $\mathrm{X}^{2}<0.05$ the null hypothesis is rejected. Loading factor or Lamda value $(\lambda)$ was used to measure the value of fit from all of factors. Lamda value $(\lambda)$ or regression weight is significant if $(\lambda) \neq 0$. Significant value was tested by the formula :

$$
\mathrm{CR}=\frac{\text { estimate }}{\text { SEE }} \geq 2
$$

where:

$\mathrm{CR}=$ Critical Ratio; $\mathrm{SEE}=$ Standart Error of Estimate

If $\mathrm{CR} \geq 2$, coefficient of loading factor was significant and there was additional test of structural model analysis.

\section{RESULTS AND DISCUSSION}

\section{Profile of Beef Cattle Farming in Central Java}

The beef catlle development in Central Java has a important role in bringing about significant changes in the socio-economic structure of the rural economy. Beef cattle farming is a class of agricultural on an animal husbandry enterprise which is practised many farmers. The population of beef cattle has increased approximately $1.348 \%$ in 5 years (2004-2008). All the 29 districts in Central Java have beef cattle farms, with 5 Districts having the largest number of beef cattle (Blora, Grobogan, Rembang, Boyolali and Wonogiri), which is described in Table 3.

Location Quotient (LQ) was used to analyze the potency of beef cattle agribusiness

Table 1. The Index Indicates of $t$ he Agribusiness Implementation' level

\begin{tabular}{ccl}
\hline No. & Index (\%) & \multicolumn{1}{c}{ Level } \\
\hline 1. & $0.00-25.00$ & Not good (not to apply agribusiness subsystem) \\
2. & $25.01-50.00$ & Somewhat good (it has low level of the application of agribusiness) \\
3. & $50.01-75.00$ & Moderate (it has moderate level of the application of agribusiness) \\
4. & $75.01-100.00$ & Good (it has high level of the application of agribusiness) \\
\hline
\end{tabular}


Table 2. The Variables of $\mathrm{X}$ and $\mathrm{Y}$

\begin{tabular}{|c|c|c|}
\hline Items & & Notation \\
\hline Upstream Agribusiness System & $\mathrm{X}_{1}$ & \\
\hline 1. Breed & & $\mathrm{X}_{11}$ \\
\hline 2. Forage feed & & $\mathrm{X}_{12}$ \\
\hline 3. Another Feed & & $X_{13}$ \\
\hline 4. Vaksin & & $\mathrm{X}_{14}$ \\
\hline 5. Semen & & $\mathrm{X}_{15}$ \\
\hline 6. Labour & & $\mathrm{X}_{1}$ \\
\hline Onfarm agribusiness system & $\mathrm{X}_{2}$ & \\
\hline 1. Location & & $\mathrm{X}_{21}$ \\
\hline 2. Technology & & $X_{22}$ \\
\hline 3. Onfarm sustainable system & & $X_{23}$ \\
\hline Down-stream agribusiness & $X_{3}$ & \\
\hline 1. Financial capital & & $\mathrm{X}_{31}$ \\
\hline 2. Labour & & $X_{32}$ \\
\hline 3. Management & & $X_{33}$ \\
\hline 4. Equipment & & $\mathrm{X}_{34}$ \\
\hline 5. Efficiency of management & & $X_{35}$ \\
\hline 6. $\quad$ Product quality & & $X_{36}$ \\
\hline 7. Selling Price & & $X_{37}$ \\
\hline Marketing subsystem & $\mathrm{X}_{4}$ & \\
\hline 1. Purchase & & $X_{41}$ \\
\hline 2. Selling & & $X_{42}$ \\
\hline 3. Transport & & $X_{43}$ \\
\hline 4. Storage & & $X_{44}$ \\
\hline 5. Financial & & $X_{45}$ \\
\hline 6. Risk Factor & & $X_{46}$ \\
\hline 7. Market information & & $\mathrm{X}_{47}$ \\
\hline Supporting Institution & $\mathrm{X}_{5}$ & \\
\hline 1. Financial institution & & $\mathrm{X}_{51}$ \\
\hline 2. Farmer group(“Gapoktan”) & & $\mathrm{X}_{52}$ \\
\hline 3. Market & & $X_{53}$ \\
\hline 4. Cooperative & & $\mathrm{X}_{54}$ \\
\hline 5. Research Institution & & $\mathrm{X}_{55}$ \\
\hline 6. Animal Health Institution & & $\mathrm{X}_{56}$ \\
\hline Implementation of Agribusiness & $Y_{1}$ & \\
\hline 1. Increasing population & & $\mathrm{Y}_{11}$ \\
\hline 2. Income & & $Y_{12}$ \\
\hline
\end{tabular}

development. Table 3 showed that the value of the LQ are higher than 1. While the relative population of beef cattle is more or less dominant on basis sector of Central Java Province (LQ>1). Hence, beef cattle farming have potency to develop and capacity to sell the products outside the provinces. Moreover, all the stakeholders should be mobilized to help in maintaining the sustainability of the beef cattle development program.

\section{Characteristics of the Respondents}

The result of the study revealed that $89 \%$ respondents were in their productive years old and $56.5 \%$ attended primary school. Moreover, most of the respondents had experience to manage a beef cattle farming for 19.895 years. A large percentage $(81 \%)$ of the respondents worked as food crop farmers, only $4 \%$ of the respondents had main occupation as beef cattle farmers and it has 8 hours-work day.

\section{Validity and Reliability Test}

The validity test was $>1.35$, it showed that all of instruments in these study are valid. Besides that, the value of Cronbach's alpha $>0.5$, it means that all of the questions are reliable. The reliability test is presented in Table 4.

\section{Level of the application of agribusiness on the beef cattle farming}

The implementation of beef cattle agribusiness is syschronization of agribusiness activities in beef cattle farming. The index of the implementation of beef cattle agribusiness is presented in Table 5.

The index of the implementation of beef cattle agribusiness had moderate level. This can be caused by several problems, such as : high price of beef cattle breeds, the number and quality of the breeds, availability of forage in dry season, high price of concentrate and vaccine, limited access to high-quality genetics, feeding management and quality as well as limited farmer education and lack of technology for feeding practices, poor farm management practices, limited access to financial institution and price fluctuation as well as poor marketing system. Smallholders are unable to take advantage of market opportunities and must pay high costs to overcome market imperfections. Farmers often have trouble accessing credit, obtaining information on market opportunities or new technologies, purchasing certain inputs and accessing product markets. When markets are accessible, farmers may be subject to price fluctuations or inequitable prices. Such difficulties are barriers to their development and represent a bottleneck in the development process. Contract farming is potentially a way of overcoming 
Table 3. Number of Beef Cattle and Location Quotient (LQ) in 5 Districts

\begin{tabular}{|c|c|c|c|c|c|}
\hline \multirow{2}{*}{ No. } & \multirow{2}{*}{ District } & \multicolumn{2}{|c|}{2006} & \multicolumn{2}{|l|}{2008} \\
\hline & & Population (heads) & LQ & Population (heads) & LQ \\
\hline 1. & Blora & 217,497 & 3.28 & 216,898 & 3.28 \\
\hline 2. & Wonogiri & 143,995 & 0.87 & 154,300 & 1.01 \\
\hline 3. & Grobogan & 106,155 & 2.39 & 105,549 & 2.23 \\
\hline 4. & Rembang & 97,057 & 1.98 & 103,802 & 1.97 \\
\hline \multirow[t]{2}{*}{5.} & Boyolali & 88,027 & 1.38 & 86,573 & 1.38 \\
\hline & Central Java & $1,390,208$ & & $1,442,033$ & \\
\hline
\end{tabular}

Table 4. The Result of Reliability Test

\begin{tabular}{clcc}
\hline No. & Agribusiness subsystem & Cronbach's & Test \\
\hline 1. & Upstream agribusiness system & 0.881 & Reliable \\
2. & Onfarm agribusiness system & 0.805 & Reliable \\
3. & Down-stream agribusiness subsystem & 0.678 & Reliable \\
4. & Marketing subsystem & 0.700 & Reliable \\
6. & Supporting Institution & 0.700 & Reliable \\
\hline
\end{tabular}

market imperfections, minimising transaction costs and gaining market access (Simmons et al., 2004).

\section{The Analysis of the Implementation of Beef Cattle Agribusiness}

Structural Equation Model (SEM) was used to analyze subsystem agribusiness implementation to production and income. Activities analysis of each subsystem describes the relationship among agribusiness subsystem variables to agribusiness implementation. The result of beef cattle agribusiness subsystem implementation is formed to beef cattle population and farm income, it is illustrated in Figure 1.

The results of Structural Equation Model (SEM) showed that the model was feasible with Chi-Square value $=0.952 ;$ RMSEA $=0.000$; Probability $=0.621$ and TL1 $=1.126$. The goodness of fit index showed that the SEM test is accepted to have advanced analysis. It is describe on Table 6.

\section{Correlation Analysis of Variables}

The use of statistical correlation is to evaluate the strength of the relation among variables. The regression test of implementation subsystems agribusiness on the beef cattle farming is presented at Table 7 .

The relationship between exogen and endogen variables had low estimation, that mean that the effect of endogenous variables is not real to the exogenous variables as the index of the implementation of beef cattle agribusiness subsystem had moderate level, shown at Table 5. The low estimation might be happen as some factors, namely feeding management and quality as well as lack farmer education and technology for feeding practices. While, the result of correlation among endogen variables which analyzed using Maximum Likelihood Estimates test was showed through Regression Weights score, it is illustrated at Table 8 .

Result of regression weight score of the agribusiness subsystem implementation which is shown on Critical Ratio (CR) and probability value indicated that: Supporting institution (X5) to the down-stream agribusiness (X3) and the marketing subsystem (X4); marketing subsystem (X4) to the up-stream agribusiness system (X1); up-stream agribusiness system (X1) to the on-farm agribusiness system (X2); on-farm agribusiness system (X2) to the down-stream agribusiness (X3) and downstream agribusiness (X3) to the income of farmers (Y11) were significant. Based on the result, the agribusiness implementation variables were recursive process, it was one of which objects were defined in term of 
Table 5. The Index of the Implementation of Beef Cattle Agribusiness Subsystem

\begin{tabular}{clcc}
\hline No. & Agribusiness subsystem & Value & Criteria \\
\hline 1. & Upstream agribusiness system & 0.693 & Moderate \\
2. & Onfarm agribusiness system & 0.721 & Moderate \\
3. & Down-stream agribusiness subsystem & 0.684 & Moderate \\
4. & Marketing subsystem & 0.626 & Moderate \\
5. & Supporting Institution & 0.691 & Moderate \\
\hline
\end{tabular}

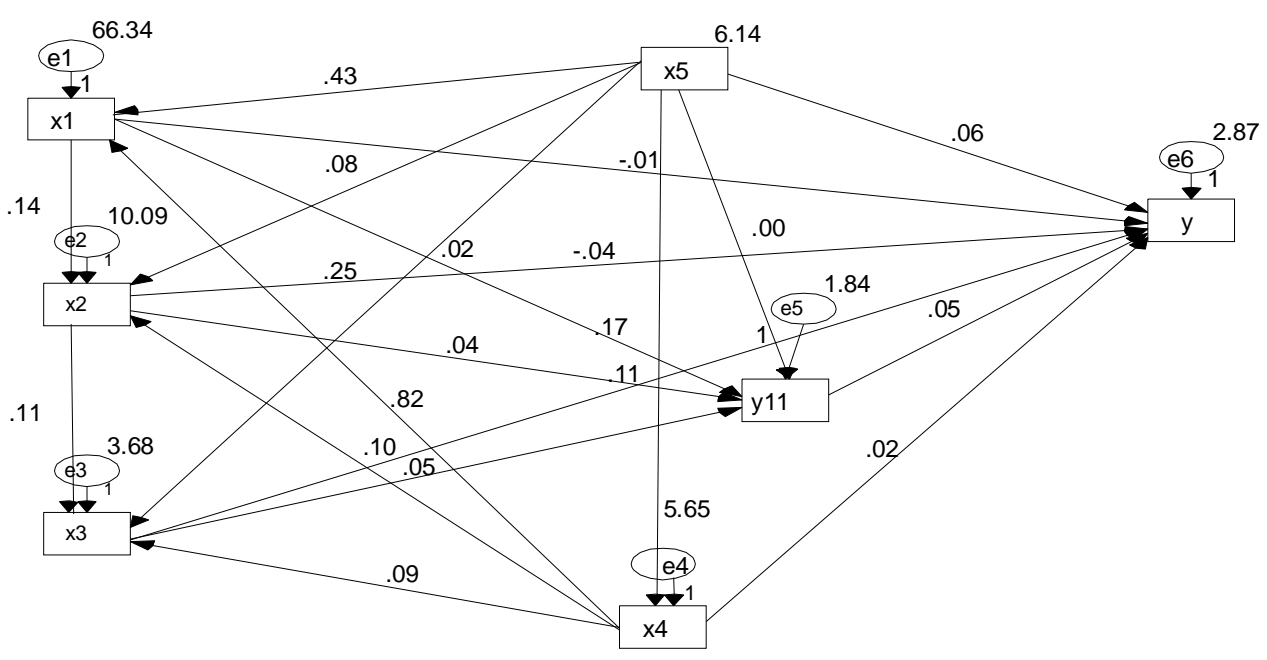

Figure 1. The Result of Structural Equation Model (SEM) among Variables on Beef Cattle Agribusiness Subsystem with the Value of Chi-Square $=0.952$; Probability $=0.621$, TLI $=1.126$ and RMSEA $=0.000$

Table 6. Goodness-of-fit Indeces

\begin{tabular}{|c|c|c|c|}
\hline Goodness of Fit Index & Cut-off Value & Result & Note \\
\hline Chi-square $\left(X^{2}\right)$ & low & 0.952 & Appropriate \\
\hline Significance probability & $\geq 0.05$ & 0.621 & Appropriate \\
\hline Relative $X^{2}$ (CMINDF/DF) & $\leq 2.00$ & 0.476 & Appropriate \\
\hline Goodness of Fit Index (GFI) & $\geq 0.90$ & 0.999 & Appropriate \\
\hline Adjusted Goodness of Fit Index (AGFI) & $\geq 0.90$ & 0.981 & Appropriate \\
\hline Parsimony Goodness of It Index (PGFI) & $\geq 0.50$ & 0.771 & Appropriate \\
\hline Normed Fit Index (NFI) & $\geq 0.95$ & 0.991 & Appropriate \\
\hline Relative Fit Index (RFI) & $\geq 0.95$ & 0.980 & Appropriate \\
\hline Incremental Fit Index (IFI) & Close to 1.0 & 1.010 & Appropriate \\
\hline Tucker Lewis Index (TLI) & $\geq 0.95$ & 1.126 & Appropriate \\
\hline Comparative Fit Index (CFI) & $\geq 0.95$ & 1.000 & Appropriate \\
\hline Non Centrality Parameter (NCP) & $X^{2}$ & 0.000 & Appropriate \\
\hline $\begin{array}{l}\text { The Root Mean Square Error of } \\
\text { Approximation (RMSEA) }\end{array}$ & $\leq 0.08$ & 0.000 & Appropriate \\
\hline
\end{tabular}

other objects of the same type or process of repeating items in a self-similar way.
The result analysis shown each variable had relation, it means that each subsystem can not 
Table 7. Relationship between Exogen Variable (Implementation of Agribusiness) and Endogen Variables

Relationship between Exogen Variable (Implementation of agribusiness) with

Code Estimation

\begin{tabular}{lcccc}
\hline Up-stream agribusiness & $\mathrm{Y}$ & $\leftarrow$ & $\mathrm{X}_{1}$ & 0.050 \\
On-farm agribusiness & $\mathrm{Y}$ & $\leftarrow$ & $\mathrm{X}_{2}$ & 0.038 \\
Down-stream agribusiness & $\mathrm{Y}$ & $\leftarrow$ & $\mathrm{X}_{3}$ & 0.110 \\
Marketing subsystem & $\mathrm{Y}$ & $\leftarrow$ & $\mathrm{X}_{4}$ & 0.016 \\
Supporting Institution & $\mathrm{Y}$ & $\leftarrow$ & $\mathrm{X}_{5}$ & 0.055 \\
\hline
\end{tabular}

Table 8. Regression Weight Score of the Agribusiness Implementation

\begin{tabular}{|c|c|c|c|c|c|c|}
\hline & & & Estimate & S.E. & C.R. & $\mathrm{P}$ \\
\hline $\mathrm{x} 4$ & $\leftarrow$ & $x 5$ & 0.174 & 0.068 & 2.560 & $* * *$ \\
\hline $\mathrm{x} 1$ & $\leftarrow$ & $\mathrm{x} 5$ & 0.427 & 0.237 & 1.802 & 0.072 \\
\hline $\mathrm{x} 1$ & $\leftarrow$ & $\mathrm{x} 4$ & 0.821 & 0.243 & 3.381 & $* * *$ \\
\hline $\mathrm{x} 2$ & $\leftarrow$ & $x 5$ & 0.079 & 0.093 & 0.847 & 0.397 \\
\hline $\mathrm{x} 2$ & $\leftarrow$ & $\mathrm{x} 4$ & 0.052 & 0.097 & 0.530 & 0.596 \\
\hline $\mathrm{x} 2$ & $\leftarrow$ & $\mathrm{x} 1$ & 0.140 & 0.028 & 5.046 & $* * *$ \\
\hline $\mathrm{x} 3$ & $\leftarrow$ & $\mathrm{x} 5$ & 0.248 & 0.056 & 4.432 & $* * *$ \\
\hline $\mathrm{x} 3$ & $\leftarrow$ & $\mathrm{x} 4$ & 0.093 & 0.058 & 1.618 & 0.106 \\
\hline $\mathrm{x} 3$ & $\leftarrow$ & $\mathrm{x} 2$ & 0.110 & 0.040 & 2.729 & $* * *$ \\
\hline y11 & $\leftarrow$ & $\mathrm{x} 1$ & 0.016 & 0.012 & 1.308 & 0.191 \\
\hline y11 & $\leftarrow$ & $\mathrm{x} 2$ & 0.044 & 0.031 & 1.434 & 0.152 \\
\hline y11 & $\leftarrow$ & $x 5$ & -0.002 & 0.042 & -0.047 & 0.962 \\
\hline y11 & $\leftarrow$ & $\mathrm{x} 3$ & 0.101 & 0.050 & 2.014 & $* * *$ \\
\hline $\mathrm{Y}$ & $\leftarrow$ & $\times 5$ & 0.055 & 0.052 & 1.055 & 0.292 \\
\hline $\mathrm{Y}$ & $\leftarrow$ & $\mathrm{x} 4$ & 0.016 & 0.052 & 0.307 & 0.759 \\
\hline $\mathrm{Y}$ & $\leftarrow$ & $\mathrm{x} 1$ & -0.005 & 0.016 & -0.339 & 0.735 \\
\hline $\mathrm{Y}$ & $\leftarrow$ & $\mathrm{x} 2$ & -0.038 & 0.039 & -0.990 & 0.322 \\
\hline $\mathrm{Y}$ & $\leftarrow$ & $\mathrm{x} 3$ & 0.110 & 0.063 & 1.743 & 0.081 \\
\hline $\mathrm{Y}$ & $\leftarrow$ & y11 & 0.049 & 0.088 & 0.550 & 0.582 \\
\hline S.E. & \multicolumn{3}{|c|}{ : Standard Error } & \multicolumn{3}{|c|}{$\mathrm{X} 1$ : up-stream agribusiness } \\
\hline C.R. & \multicolumn{3}{|c|}{ : Critical Ratio } & \multicolumn{3}{|c|}{$\mathrm{X} 2$ : on-farm agribusiness } \\
\hline $\mathrm{P}$. & \multicolumn{3}{|c|}{ : Probability } & \multicolumn{3}{|c|}{ X3: down-stream agribusiness } \\
\hline Y. & \multicolumn{3}{|c|}{ : agribusiness implementation } & \multicolumn{3}{|c|}{ X4: marketin system } \\
\hline Y11 & \multicolumn{3}{|c|}{ : increasing population } & \multicolumn{3}{|c|}{ X5: supporting institution } \\
\hline
\end{tabular}

stand up alone. Supporting institution was important for marketing subsystem and downstream agribusiness as the agribusiness production which had been managed on post harvest needed the supporting institution to facilitate production distribution. The result was in line to Prasetyo's finding (2005) that most farmers had no bargaining position for marketing, they need institution intervencing to increase added value production. Whereas, marketing subsystem was needed for supplying some input factors for on farm agribusiness and distributing agribusiness production. In addition, down-stream subsystem agribusiness which well managed can increase the added value of production. It was shown on the significant value of variables. 
Meanwhile, some agribusiness variables such as upstream, on-farm and down-stream agribusiness were not significant to the production and income. Some factors influencing the result were farming subsystem tends to be dominated by farm small-scale which will produce vary production not only quality but also quantity. This condition can make a higher transaction cost whereas it was the important component for agribusiness (Saragih, 2000). Besides that, the approach of adaptive technology is needed to develop on-farm subsystem agribusiness. This is one of the essential factors on farm development especially livestock agribusiness (Tawaf and Firman, 2005). Other essential factors which influence the agribusiness implementation were marketing for agriculture production, local input, production incentive for farmers and transportation preparation.

Finally, the agribusiness subsystem implementation needs to develop for improving agribusiness performance. Technology development which touch to the aspect of production technique start improving of beef cattle breed quality, input factors, feeding additives, stock of equipment, supporting of farmer's skill for managing livestock agribusiness were aspect to increase agribusiness implementation. In addition, agribusiness managers and sales people, understanding customers and their preferences and behaviors is crucial to success. Understanding their current customers' buying behaviors is valuable, this information becomes much more valuable if new or potential customers can be classified by buying behavior segment. Furthermore, the classification is most useful if it is based on characteristics agribusiness managers and salespeople can easily observe or elicit by asking a few key questions (Gupta and Chintangunta, 1994; Wyner, 2000; Mudambi, 2002). While, developing effective marketing strategies, and anticipating the needs of current and future customers is one of the most significant challenges faced by agribusiness firms (Corinne et al., 2005).

\section{CONCLUSION}

The result of the study indicated that the implementation of beef cattle subsystem agribusiness had adequate index and give positive influence to the beef cattle agribusiness. The analysis of Structural Equation Model (SEM) showed that the model was feasible with Chi-
Square value $=0.952 ;$ RMSEA $=0.000$; Probability $=0.621$ and TL1=1.126. Agribusiness subsystem had a significant outcome to the implementation of beef cattle subsystem agribusiness.

\section{REFERENCES}

Arinto. 2004. Usaha dan Efisiensi Pemasaran Sapi Potong di Wilayah Pembibitan dan Pembesaran (Studi Kasus di Kabupaten Grobogan). Dissertation, Universitas Gadjah Mada, Yogyakarta.

BPS. 2009. Jawa Tengah Dalam Angka 2009. CV Nabawi, Semarang.

Corinne E.A, C.A. Wilson, and D.H. Foley. 2005. Agricultural input market segments: Who is buying what? J. of Agribusiness 23(2):113132.

Diwyanto, K. and A. Priyanti. 2006. Kondisi, Potensi dan Permasalahan Agribisnis Peternakan Ruminansia dalam Mendukung Ketahanan Pangan. Prosiding Seminar Nasional Pemberdayaan Masyarakat Peternakan di Bidang Agribisnis untuk Mendukung Ketahanan Pangan. Fakultas Peternakan Universitas Diponegoro. August 3, 2010. P.1-11.

Downey, D and S. P. Erickson. 1987. Agribusiness Management. $2^{\text {nd }}$ Edition, McGraw-Hill Book Co. Inc. New York.

Ekowati, T., E. Prasetyo and Mukson. 2006. Implementasi manajemen agribisnis pada usahatani ternak itik : Studi kasus pada KTT Srirejeki Pemalang. J. Dinamika Sosbud. 8(1):18-24.

Ferdinand, A. 2006. Structural Equation Modeling. $4^{\text {th }}$ Edition. Badan Penerbit Universitas Diponegoro, Semarang.

Gupta, S., and P. K. Chintangunta. 1994. On using demographic variables to determine

segment membership in logit mixture models. J. Marketing Research 31:128-136.

Ilham, N. 2007. Alternatif kebijakan peningkatan pertumbuhan PDB subsektor peternakan di Indonesia. Analisis Kebijakan Pertanian. 5(4): 335-357.

Mudambi, S. 2002. Branding importance in business-to-business markets: Three buyer clusters. Industrial Marketing Management. 31:525-533.

Mukson, T. Ekowati, M. Handayani and S. Gayatri. 2010. The Potency of dairy cattle agribusiness development in Semarang 
Regency, Central Java. J. of Indonesian Trop. Agric. 35(3):179-184.

Nasir, M. 1988. Metode Penelitian. Ghalia Indonesia. Jakarta.

Prasetyo, E., T. Ekowati and Mukson. 2005. Kondisi dan potensi pengembangan usahatani ternak sapi perah di Kabupaten Semarang. J. Indonesian Trop. Agric. 30(2):110-118.

Saragih, B. 2000. Agribisnis sebagai landasan pembangunan ekonomi Indonesia dalam era mulenium baru. Jurnal Studi Pembangunan, Kemasyarakatan dan Lingkungan. 2(1): 1- 9.

Simmons, P, A. Daryanto, R. Oktaviani, R. P. Yusuf, Ni W. S. Astiti, I G. Pitana, M.M. Mustadjab, N. Hanami and D. Napitupulu. 2004. Contract farming in Indonesia: Smallholders and agribusiness working together. Australian Centre for International
Agricultural Research Canberra.

Tawaf, R. and A. Firman. 2005. Analisis Pembangunan Sektor Peternakan. Fakultas Peternakan, Universitas Padjadjaran.

Thamrin, S.H. Sutjahjo, C. Herison and S. Sabiham. 2007. Analisis keberlanjutan wilayah perbatasan Kalimantan Barat Malaysia untuk pengembangan kawasan agropolitan. JAE 25(2):103-124.

Wyner, G. A. 2000. Customer classification. Marketing Research. P.38-39.

Yusdja, Y. and N. Ilham. 2004. Tinjauan kebijakan pengembangan agribisnis sapi potong. Analisis Kebijakan Pertanian 2(2):183-203.

Yusdja, Y. and N. Ilham. 2006. Arah kebijakan pembangunan peternakan rakyat. Analisis Kebijakan Pertanian. 4(1):18-38. 